\title{
Evaluation of bony fusion after anterior cervical discectomy: a systematic literature review
}

\author{
I. Noordhoek ${ }^{1} \mathbb{D} \cdot$ M. T. Koning ${ }^{2} \cdot$ C. L. A. Vleggeert-Lankamp ${ }^{1}$
}

Received: 19 May 2018 / Accepted: 4 November 2018 / Published online: 17 November 2018

(C) The Author(s) 2018

\begin{abstract}
Purpose Anterior cervical discectomy and fusion (ACDF) has proven effective in treating radicular arm pain. Post-operatively, cervical spine stability is temporarily challenged, but data on bony fusion and speed of fusion are ambiguous; optimum evaluation method and criteria are debated.

Aim To study bony fusion accomplishment and to obtain an overview of methods to evaluate fusion.

Methods A literature search was performed in PubMed and Embase. Included studies had to report original data concerning 1- or 2-level ACDF with intervertebral device or bone graft, where bony fusion was assessed using CT scans or X-rays. Results A total of 146 articles comprising 10,208 patients were included. Bony fusion was generally defined as "the presence of trabecular bridging" and/or "the absence of motion". Fusion was accomplished in $90.1 \%$ of patients at the final follow-up. No gold standard for assessment could be derived from the results. Addition of plates and/or cages with screws resulted in slightly higher accomplishment of fusion, but differences were not clinically relevant. Eighteen studies correlated clinical outcome with bony fusion, and 3 found a significant correlation between accomplishment and better clinical outcome.

Conclusions In approximately $90 \%$ of patients, bony fusion is accomplished one year after ACDF. As there is no generally accepted definition of bony fusion, different measuring techniques cannot be compared to a gold standard and it is impossible to determine the most accurate method. Variations in study design hamper conclusions on optimising the rate of bony fusion by choice of material and/or additives. Insufficient attention is paid to correlation between bony fusion and clinical outcome.
\end{abstract}

Graphical abstract These slides can be retrieved from electronic supplementary material.
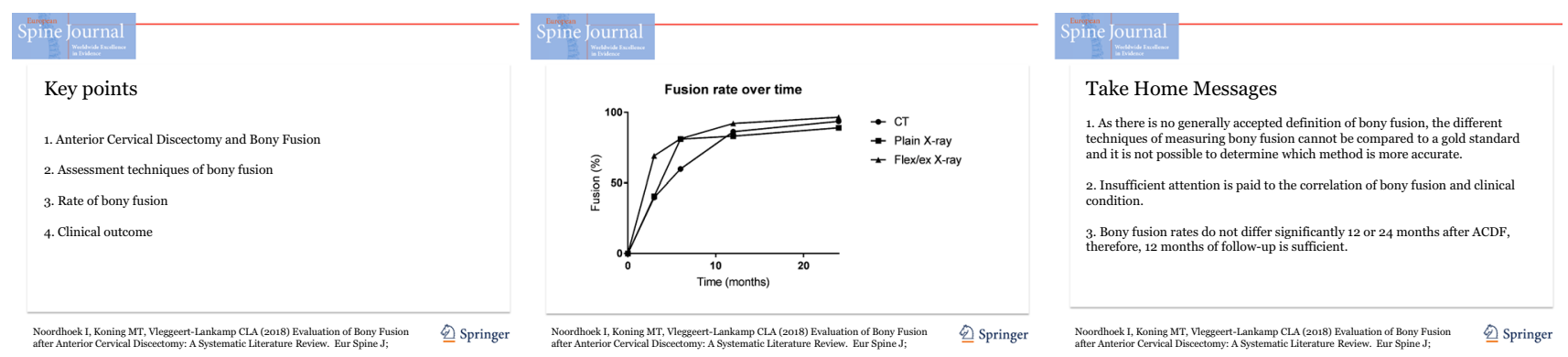

Keywords Anterior cervical discectomy and fusion $\cdot$ Radiologic techniques $\cdot$ Speed of fusion $\cdot$ Clinical outcome

Electronic supplementary material The online version of this article (https://doi.org/10.1007/s00586-018-5820-9) contains supplementary material, which is available to authorized users.

I. Noordhoek

i.noordhoek@1umc.nl

Extended author information available on the last page of the article

\section{Introduction}

Anterior cervical discectomy and fusion (ACDF) is a commonly used procedure to decompress cervical spinal nerves or the cervical medulla. The "discectomy" refers to the removal of the intervertebral disc including the herniated part to provide decompression of the nervous tissue. 
The "fusion" part refers to the additional surgical procedure to stabilize the two adjacent vertebrae which will, theoretically, be compromised after removing the intervertebral disc. In order to provide surgical fusion, it is usual care to place an intervertebral device, like a bone graft or a cage, between the vertebra to replace the disc tissue and to maintain foraminal height. This procedure can be accompanied by anterior plating, which is assumed to add to the stability of the spine. Subsequent "bony fusion" is deemed to follow upon consolidation of the bone between the adjacent vertebrae through and along the intervertebral device. The intervention is regarded to lead to solid arthrodesis and to carry minimal surgical risks [1-3]. It is slightly confusing that "surgical fusion" and "bony fusion" are in general both referred to as "fusion".

Autologous iliac bone grafts as well as cages made from titanium, polyether ether ketone (PEEK) and various other materials are commonly used as intervertebral devices. Although cages can differ in shape and material, they are all intended to maintain height and to add to immobilization of the degenerated motion segment [4].

Firm immobilization is only effectuated once bony fusion has been accomplished. Anterior discectomy temporarily challenges the stability of the cervical spine postoperatively, and this can theoretically lead to kyphotic malalignment [5], which can give rise to neck disability and pain and, ultimately, to neurological deficits. In order to avoid these complications, patients' daily activities are restricted until bony fusion has been accomplished.

However, knowledge about the process of bony fusion is limited. Firstly, it is debated what the timing of bony fusion is after a discectomy was carried out. Secondly, the method to judge bony fusion is not equivocal. Finally, the correlation between bony fusion and clinical outcome is unknown.

The primary objective of this systematic review is to study the process of bony fusion and to obtain an overview of methods to evaluate bony fusion. Secondary objectives are to compare results based on evaluation methodology, cage or graft material and addition of bone stimulating agents, and to assess whether there is a correlation between clinical outcome and bony fusion accomplishment.

\section{Methods}

\section{Data searches and study selection}

To obtain all relevant literature, the electronic databases PubMed and Embase were searched on 14 January 2016. The search strings presented in Table 1 were used. According to PRISMA guidelines, two of the authors (IN and MTK) individually and independently screened the articles for predefined inclusion criteria. These were stated as follows:

- The article was published in English or Dutch;

- The article was an original report presenting primary data;

- The article was published on or after 1 January 2000;

- The study had a minimum of 10 patients;

- The study focused on the cervical spine (C2-Th1);

- The study presented patients undergoing a 1- or 2-level anterior cervical discectomy and fusion with an intervertebral device (exempting prostheses) or a bone graft;

- The included patients did not undergo revision surgery or surgery as treatment for trauma;

Table 1 Search strings used for the data search in January 2016

\begin{tabular}{|c|c|}
\hline Category & Search string \\
\hline Discectomy (1) & $\begin{array}{l}\text { "ACDF”[tiab] OR “discectomy”[tiab] OR “diskectomy”[tiab] OR “Diskectomy”[Mesh] OR diskectom*[tiab] OR } \\
\text { discectom*[tiab] OR “Anterior Cervical Discectomy and Fusion"[all fields] OR "Anterior Cervical Diskectomy } \\
\text { and Fusion”[all fields] }\end{array}$ \\
\hline Cervical spine (2) & $\begin{array}{l}\text { "Cervical Vertebrae"[Mesh] OR "cervical vertebrae"[all fields] OR "cervical vertebra"[all fields] OR "cervical } \\
\text { spine"[all fields] OR "cervical”[tiab] }\end{array}$ \\
\hline Fusion (3) & $\begin{array}{l}\text { “Spinal Fusion”[mesh] OR “spinal fusion”[all fields] OR “fusion”[tiab] OR “spondylodesis”[all fields] OR “non- } \\
\text { union”[all fields] }\end{array}$ \\
\hline Intervertebral device (4) & 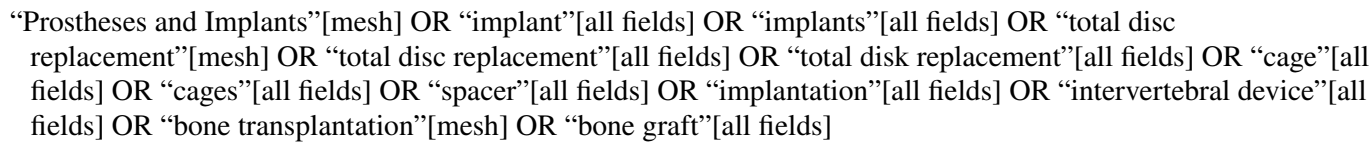 \\
\hline Combined search string & (1) AND (2) AND (3) AND (4) \\
\hline Results & $14 / 01 / 2016$ \\
\hline PubMed & 1018 results \\
\hline $\begin{array}{l}\text { Embase (search string } \\
\text { adjusted accordingly) }\end{array}$ & 1099 results, 403 unique \\
\hline Total & 1421 unique results \\
\hline
\end{tabular}


- The method of assessing fusion was described;

- The study assessed fusion with CT scan or X-ray;

- The article was published in a peer-reviewed journal.

Only studies that the evaluators reached a consensus on were included. If needed, a third reviewer (CVL) was consulted.

\section{Quality assessment}

To assess the quality of the selected studies, the studies were evaluated with the aid of an adjusted version of the Dutch Cochrane Centre checklist for cohort studies, presented in Table 2. The methodological requirements and objectives of these studies were closely evaluated. This was done individually and independently by two reviewers (IN and CVL). Studies were assessed on selection bias, outcome bias and follow-up bias, each category accounting for a maximum of 3 points. In total, a study could be awarded a maximum of 9 points. Studies were then divided into a low (5-9 points) or high ( 4 or less points) risk of bias group using a method adapted from Furlan et al. [6].

\section{Data extraction}

All data from the included studies were analysed, and data regarding the following items were extracted:

- Number of participating patients;

- Mean time and range of follow-up;

- Percentage of fusion at 3,6,12 and 24 months and at final follow-up;

- Method of measuring bony fusion;

- Use of bone growth stimulation;

- Distribution of patients over different implant types;

- Use of plate and/or screws;
- Clinical outcome and correlation to bony fusion;

- Contact area and height of the implant.

\section{Statistical analysis}

Descriptive analyses were performed using paired t-tests, and dichotomous data were analysed using Chi-square tests with Yates' correction. $P$ values of less than or equal to 0.05 were considered statistically significant.

Clinical relevance was assessed using the method described by Ostelo et al. [7], who defined absolute cutoff values for multiple clinical outcome measures and proposed a minimal clinically important difference (MCID) as an improvement of $30 \%$ or more in respect of the baseline value as a general rule.

\section{Results}

\section{Characteristics of included studies}

Through our search, 1421 unique studies were identified. After matching these to our inclusion criteria, 146 studies were included. The most common grounds to exclude studies were as follows: patients did not undergo ACDF, bony fusion was not properly described, and patient numbers were too small, as shown in Fig. 1.

Combining all studies resulted in a cohort of 10,208 patients, of whom 3200 received a bone graft (including allogenic and autologous bone), 4671 received a polyether ether ketone (PEEK) cage, 348 received a poly(methyl methacrylate) (PMMA) cage, 239 received a carbon fibre cage, and 1750 received a titanium cage (Fig. 2).
Table 2 Quality assessment checklist

\begin{tabular}{|c|c|}
\hline & Award 1 point if \\
\hline \multicolumn{2}{|l|}{ Selection bias (3 pts.) } \\
\hline Goal and inclusion & Goal of the study is stated and study explicitly states the inclusion criteria \\
\hline Selection of patients & Selective recruitment of patients can be ruled out \\
\hline Patient characteristics & Study reports the age range and mean age and states the distribution of gender \\
\hline \multicolumn{2}{|l|}{ Outcome bias ( 3 pts.) } \\
\hline Definition of fusion & Definition classification and radiological tools to measure fusion were stated \\
\hline Clinical outcome & Clinical outcome was systematically evaluated in correlation with fusion \\
\hline Radiographic method & Fusion was measured through CT scan \\
\hline \multicolumn{2}{|l|}{ Follow-up bias ( 3 pts.) } \\
\hline Follow-up time frame & Follow-up range, period and mean were given and loss to follow-up $<20 \%$ \\
\hline Prospective study & Data in the study were collected prospectively \\
\hline Multiple moments & Follow-up was divided into multiple moments in time \\
\hline Total (9 pts.) & \\
\hline
\end{tabular}


Fig. 1 Flow chart of excluding studies. $A C D F$ anterior cervical discectomy and fusion

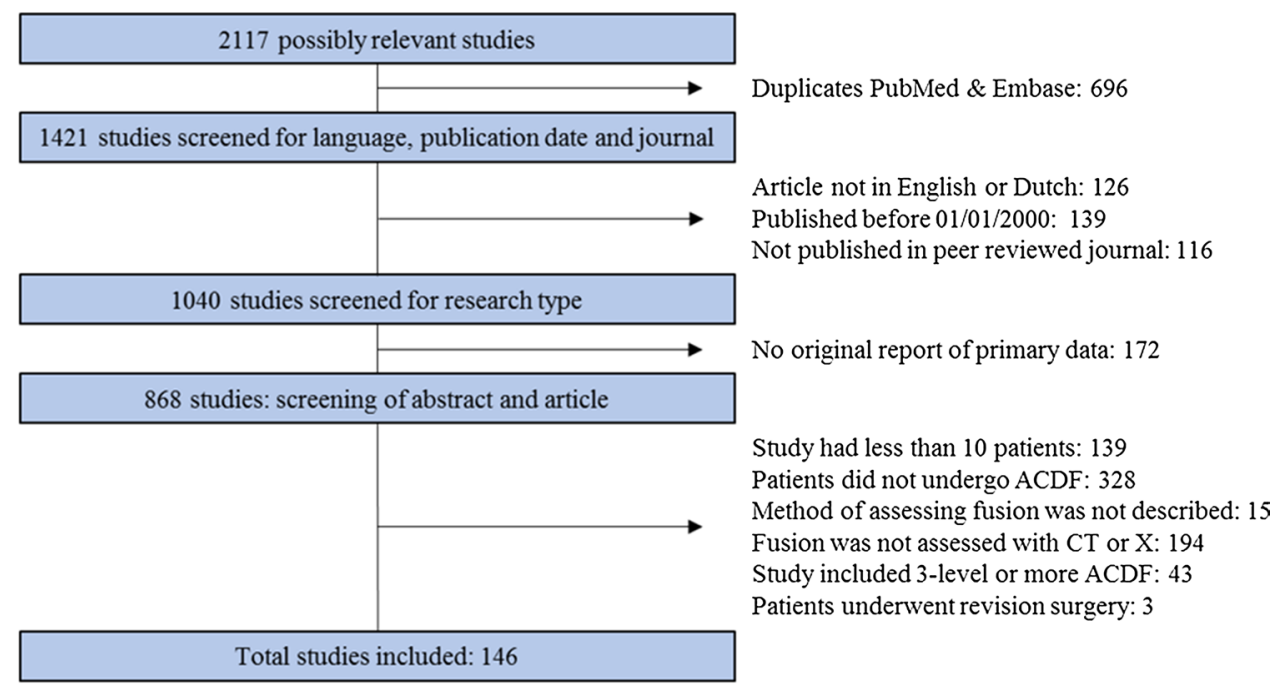

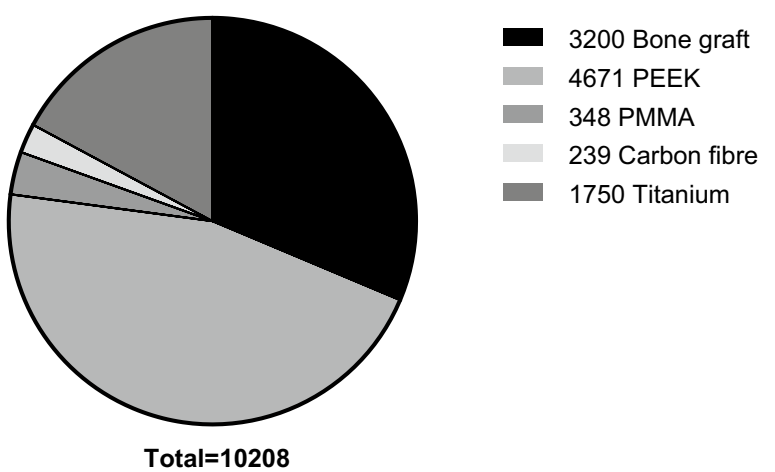

Fig. 2 Distribution of implants over patients. PEEK polyether ether ketone. PMMA poly(methyl methacrylate)

\section{Risk of bias}

A total of 119 studies were assessed to have a low risk of bias, and 27 studies showed a high risk of bias. When comparing studies with a low and high risk of bias, the difference mainly seems to be due to outcome and follow-up bias, since studies with a high risk of bias generally did not divide follow-up into multiple moments in time and did not investigate the correlation between clinical outcome and bony fusion.

\section{Bony fusion}

Among many other definitions, bony fusion was most commonly defined as the presence of trabecular bridging on X-rays or CT scans and/or absence of motion on flexion/extension radiographs. Realization of bony fusion was generally reported at the final follow-up moment (FFU). The median time to FFU was 20.5 months, with a range of 3-408 months. At FFU, studies report accomplished bony fusion in a mean of $90.1 \%$ of patients, ranging from one
Table 3 Fusion rate over time

\begin{tabular}{lllll}
\hline $\begin{array}{l}\text { Time point } \\
\text { (months) }\end{array}$ & Studies $(n)$ & $\begin{array}{l}\text { Mean risk of } \\
\text { bias score }\end{array}$ & Patients $(n)$ & Fusion (\%) \\
\hline 3 & 18 & 6.4 & 1420 & 51.1 \\
6 & 44 & 6.1 & 3129 & 78.3 \\
12 & 53 & 5.9 & 4202 & 87.6 \\
24 & 29 & 6.1 & 2174 & 92.6 \\
\hline
\end{tabular}

study reporting 30\% [8] to studies reporting 100\% [9-67]. Studies with a high risk of bias reported statistically significantly higher numbers of patients in which bony fusion was accomplished than studies with a low risk of bias $(94.0 \%$ and $89.4 \%$, respectively; $p<0.0001$ ). The rate of bony fusion (accomplishment of fusion in a particular patient over time) was studied in approximately half of the included articles, in which accomplishment of bony fusion was measured at 3,6, 12 and 24 months follow-up (Table 3, Fig. 3) [4, 8-11, 13, 15-17, 20, 21, 23-25, 27, 30-32, 34, 38, 40-42, 45, 47-51, 54, 55, 57, 59-65, 67-97]. Significantly higher bony fusion accomplishment rates are observed after longer periods of follow-up; however, the difference in accomplishment of bony fusion between 12 months and 24 months follow-up is not clinically relevant.

\section{Methods of measuring bony fusion}

Trabecular bridging as a sign of accomplishment of bony fusion was determined in 26 studies evaluating CT scans and in 63 studies evaluating plain antero-posterior and/or lateral X-rays. Motion on lateral flexion/extension X-rays as a sign of accomplishment of bony fusion was determined in 55 studies. In 17 studies, the angulation changes at the target level were measured, and in 11 studies, the difference in 


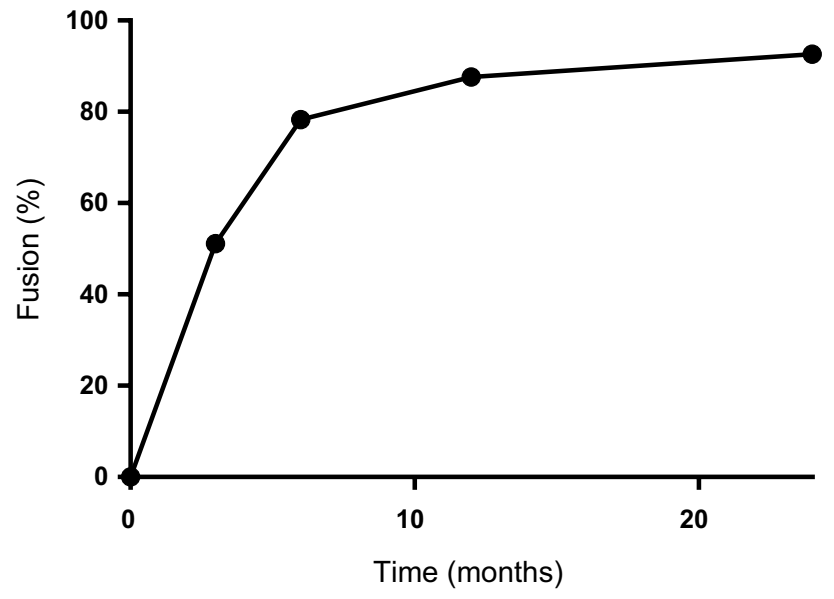

Fig. 3 Fusion rate over time

Table 4 Overview of different radiological methods of measuring fusion

\begin{tabular}{lllll}
\hline Method & $\begin{array}{l}\text { Mean risk } \\
\text { of bias } \\
\text { score }\end{array}$ & Patients $(n)$ & $\begin{array}{l}\text { Median time } \\
\text { to final FU } \\
\text { (months) }\end{array}$ & Fusion (\%) \\
\hline CT & 6.5 & 1528 & 15.3 & 90.1 \\
X-plain & 5.4 & 3963 & 23.2 & 88.3 \\
X-flex/ex & 5.3 & 4571 & 15.9 & 91.7 \\
\hline
\end{tabular}

$F U$ follow-up

interspinous distances upon flexion and deflexion was measured. In 27 studies, the method was not further defined. At FFU, bony fusion was accomplished in $90.1 \%$ of patients in studies using $\mathrm{CT}$ scanning, bony fusion in studies using plain $\mathrm{X}$-rays was $88.3 \%$, and bony fusion in studies using flexion/ extension X-rays was $91.7 \%$ (Table 4). The cut-off points in angulation changes and differences in interspinous distances on flexion/extension X-rays vary between articles (Table 5). This did, however, not lead to different bony fusion percentages for the angulation studies, but did lead to differences in the interspinous distance studies. Remarkably, fusion percentages were higher in those studies that allowed 0-mm difference as an upper border for movement in contrast to those that allowed up to 3-mm movement.
Measuring bony fusion by judging trabecular bridging on plain X-rays resulted in significantly lower bony fusion accomplishment than using flexion/extension X-rays $(p<0.0001)$. There was no statistically significant difference in bony fusion accomplishment comparing trabeculae on CT scans and flexion/extension X-rays $(p=0.06)$ or trabecular judgment on CT scans and plain X-rays $(p=0.077)$. A subgroup analysis was performed with the studies measuring fusion at 3-, 6-, 12- and 24-month follow-ups (Fig. 4). Gradual increase in the patients that attained bony fusion over the range of the year after surgery is observed. Again, significantly higher bony fusion accomplishment rates are observed after longer periods of follow-up, though the difference in accomplishment of fusion between 12-month and 24-month follow-ups is again not clinically relevant.

In 38 of the 146 articles, it was mentioned whether the radiographs were analysed by a radiologist or a clinician. In 26 of these, analysis was performed by a radiologist [10, $13,20,24,32,49,50,54,57,58,64,74,85,94,97-108]$. They found fusion was achieved in $93.5 \%$ of patients after a median follow-up of 23 months. In the other 12 articles, the analysis was performed by a clinician, usually a neuro- or orthopaedic surgeon $[12,29,35,61,67,69$, $87,92,96,109-111]$. They found fusion was achieved in $85.5 \%$ of patients after a median follow-up of 23 months. This difference in fusion accomplishment was statistically significant $(p<0.0001)$.

Inter-observer variability was only scarcely documented and could therefore not be analysed.

\section{Correlation fusion and type of implant}

At FFU, bony fusion was achieved in $91.4 \%$ of patients with bone grafts, in $89.1 \%$ of patients with PEEK-cages, in $83.4 \%$ of patients with PMMA-cages, in $92.9 \%$ of patients with carbon fibre cages and in $91.3 \%$ of patients with titanium cages (Table 6). As the median time to FFU varied greatly, the different bony fusion percentages cannot be compared.
Table 5 Overview of measuring fusion using flexion/extension radiographs

\begin{tabular}{lclclc}
\hline Cut-off levels & Studies $(n)$ & $\begin{array}{l}\text { Mean risk of } \\
\text { bias score }\end{array}$ & Patients $(n)$ & $\begin{array}{l}\text { Median time to final } \\
\text { follow-up (months) }\end{array}$ & Fusion (\%) \\
\hline $0 \mathrm{~mm}$ & 1 & 3.0 & 21 & 12.0 & 91.3 \\
$\leq 2 \mathrm{~mm}$ & 9 & 5.7 & 790 & 18.0 & 80.0 \\
$\leq 3 \mathrm{~mm}$ & 1 & 7 & 66 & 16.0 & 85.0 \\
$\leq 2^{\circ}$ & 15 & 5.2 & 1149 & 23.7 & 93.9 \\
$\leq 4^{\circ}$ & 2 & 6.5 & 248 & 24.0 & 94.9 \\
Unspecified & 27 & 5.1 & 2297 & 14.0 & 94.4 \\
\hline
\end{tabular}




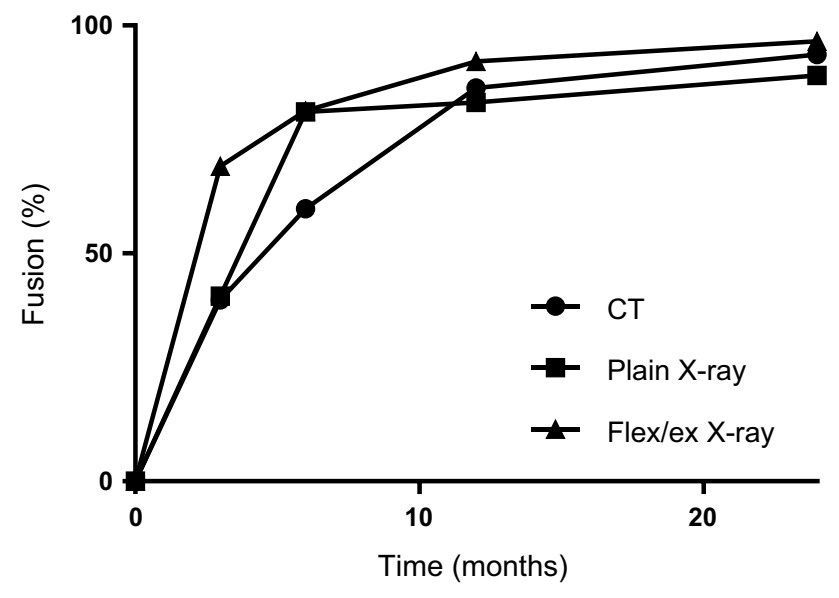

Fig. 4 Fusion rate over time, stratified per radiologic technique

Table 6 Distribution of fusion and patients over different cage types

\begin{tabular}{llrll}
\hline Material & $\begin{array}{l}\text { Mean risk } \\
\text { of bias } \\
\text { score }\end{array}$ & Patients $(n)$ & $\begin{array}{l}\text { Median time } \\
\text { to final FU } \\
\text { (months) }\end{array}$ & Fusion (\%) \\
\hline Bone graft & 5.5 & 3200 & 22.0 & 91.4 \\
PEEK & 5.5 & 4671 & 15.5 & 89.1 \\
PMMA & 5.4 & 348 & 12.0 & 83.4 \\
Carbon fibre & 6.0 & 239 & 13.0 & 92.9 \\
Titanium & 5.6 & 1750 & 24.0 & 91.3 \\
\hline
\end{tabular}

FU follow-up, PEEK poly-ether-etherketone, PMMA poly-methylmethacrylate

Table 7 Distribution of fusion over screw and plate additions

\begin{tabular}{llrll}
\hline Method & $\begin{array}{l}\text { Mean risk } \\
\text { of bias } \\
\text { score }\end{array}$ & Patients $(n) \begin{array}{l}\text { Median time } \\
\text { final follow-up } \\
\text { (months) }\end{array}$ & Fusion (\%) \\
\hline Plate/screws & 5.4 & 3971 & 21.0 & 91.4 \\
Screws & 5.6 & 499 & 15.3 & 96.6 \\
Stand-alone & 5.6 & 5738 & 20.7 & 88.6 \\
\hline
\end{tabular}

\section{Correlation bony fusion and use of plates and/ or screws}

There were 3971 patients who received a plate in addition to the implant. At FFU, bony fusion was reported in $91.4 \%$ of patients. There were 499 patients who received a cage with screws attached (no plate). At FFU, bony fusion was accomplished in $96.6 \%$ of these patients. A total of 5738 received a stand-alone implant, without addition of a plate and/or screws. At FFU, the bony fusion rate in these patients was $88.6 \%$ (Table 7). In patients treated with a cage with screws attached (no plate), the bony fusion accomplishment was significantly higher than in patients treated with stand-alone implants and implants with plates $(p<0.0001)$. In patients treated with stand-alone implants, bony fusion accomplishment was also significantly lower than in patients treated with implants with plates $(p<0.0001)$. These differences can, however, not be concluded to be clinically relevant.

\section{Using bone growth stimulation}

The different types of bone growth stimulating agents that were used are autologous bone in 3985 patients, allogenic bone in 690 patients, freeze-dried cadaveric allogenic bone in 1188 patients, $\beta$-tricalcium phosphate in 474 patients, plasmapore coating in 424 patients, hydroxy-apatite in 311 patients, no filling in 1724 patients and 17 other types of bone growth stimulating agents spread over 1412 patients (Fig. 5). The distribution of accomplishment of bony fusion over the different types of agents is shown in Table 8. As the median time to FFU varied greatly, the different bony fusion results cannot be compared.

\section{Correlation of bony fusion and height and surface of implant}

Dimensional aspects of the implants were described in 19 studies $[19,27,42,45,50,51,53,72,74,77,81,85$, 94, 111-116]. Only the study by Yoo et al. [116] assessed
Fig. 5 Distribution of bone growth stimulating agents over patients

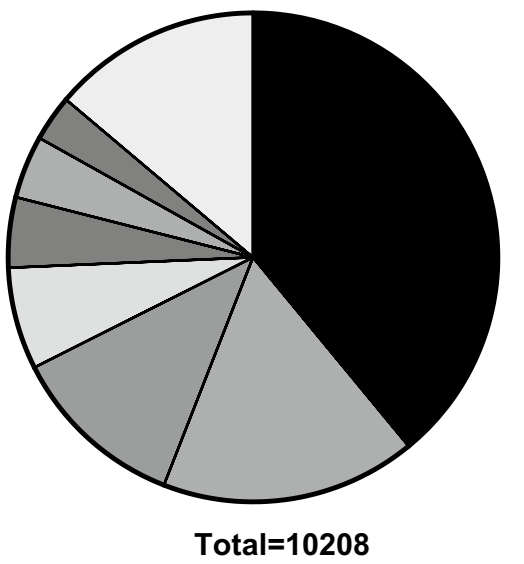

3985 Autologous bone

1724 No agent

1188 Freeze dried cadaveric allograft 690 Allogenic bone

$474 \beta$-Tricalcium phosphate

424 Plasmapore coating

311 Hydroxy-apatite

1412 Other 
Table 8 Distribution of fusion over bone growth stimulating agents

\begin{tabular}{lllll}
\hline Type & $\begin{array}{l}\text { Mean risk } \\
\text { of bias } \\
\text { score }\end{array}$ & Patients $(n)$ & $\begin{array}{l}\text { Median time } \\
\text { to final FU } \\
\text { (months) }\end{array}$ & Fusion (\%) \\
\hline Autologous & 5.5 & 3985 & 23.2 & 90.3 \\
No filling & 5.6 & 1724 & 16 & 87.4 \\
Cadaveric & 4.9 & 1188 & 23 & 91.2 \\
Allogenic & 5.3 & 690 & 17.5 & 93.3 \\
$\beta$-TCP & 5.5 & 474 & 12 & 96.8 \\
Plasmapore & 6 & 424 & 24 & 96.1 \\
HA & 5.8 & 311 & 16.1 & 74.8 \\
\hline
\end{tabular}

$F U$ follow-up, $\beta$-TCP $\beta$-tricalcium phosphate, $H A$ hydroxy-apatite

these aspects in relation to accomplishment of bony fusion. This study had a low risk of bias and found no correlation between a cage height of more than $7 \mathrm{~mm}$ and the absence of bony fusion (odds ratio $3.852 ; p=0.101$ ).

\section{Correlation between bony fusion and clinical outcome}

Clinical outcome was assessed in relation to bony fusion in 18 studies (Table 9) [25, 37, 40, 63, 84, 95, 105, 107, 109, $112,116-123]$. Of these, 17 studies had a low risk of bias and 1 study had a high risk of bias. Out of these 18 studies, 3 found a statistically significant correlation between the occurrence of bony fusion and a good clinical outcome [109, 120, 122]. The other 15 studies did not find a correlation between bony fusion and clinical outcome. Accomplishment of bony fusion in studies that did find a correlation was significantly lower than in studies that did not find a correlation $(69.3 \%$ versus $89.8 \%, p<0.0001)$. None of these studies correlated clinical outcome with accomplishment of bony fusion at different time points.

The study by Klingler et al. [109] retrospectively compared patients treated with PEEK and PMMA implants. Clinical outcome was evaluated using the visual analogue scale (VAS), the neck disability index (NDI), the short-form 36 health survey (SF-36) and the patient satisfaction index (PSI). In patients with a PMMA implant, the fusion accomplishment after a median FFU of 46 months was $47.1 \%$. Fused patients showed a statistically significant better physical component summary of the SF-36 than non-fused patients $(p=0.024)$. As the MCID for this measure is 15 [7], and the absolute difference between fused and non-fused patients is 9.2, this difference was not deemed clinically relevant. There was no correlation between bony fusion and other clinical outcome measures. In patients with a PEEK implant, fusion was accomplished in $62.2 \%$ of patients after a median FFU of 16 months. There was no correlation with any of the clinical outcome measures.
The study by Schroder et al. [120] prospectively studied patients treated with titanium cages and evaluated clinical outcome using Odom's criteria. At FFU (median 20 months), fusion was accomplished in $74.0 \%$ of patients. The occurrence of fusion was correlated with excellent and good results, whereas the absence of fusion was correlated with satisfactory and poor results $(p=0.0364)$. When using Odom's criteria, an MCID cannot be established; therefore, clinical relevance could not be assessed.

The study by Wright et al. [122] prospectively studied patients treated with autologous bone grafts and evaluated clinical outcome using VAS scores for neck pain and arm pain. At FFU (median 12 months), fusion was accomplished in $82.9 \%$ of patients. The absence of fusion was correlated with higher VAS scores for neck pain. Such correlation was not found for VAS arm pain. Absolute values were not provided in this article; therefore, clinical relevance could not be assessed.

\section{Discussion}

After ACDF surgery, bony fusion is achieved in approximately $90 \%$ of patients after a median follow-up time of 20.5 months. Bony fusion rate studies demonstrate approximately $50 \%$ of fusion after 3 months, $75 \%$ after 6 months and $90 \%$ from 12 months on. The differences between 12 and 24 months of follow-up are not clinically relevant in the overall group, or when stratified per radiologic technique. From this, it can be concluded that 12 months of follow-up is sufficient.

Methods to determine accomplishment of bony fusion seem to influence the judgement of bony fusion. Plain X-rays consistently show lower bony fusion results, even after a longer period of follow-up, and fusion results are likewise influenced by choosing cut-off levels for assessment of bony fusion. Comparable fusion results were found in comparing trabeculae on CT scans and movement on flexion/extension $\mathrm{X}$-rays. As there is no generally accepted definition of bony fusion, the different techniques cannot be compared to a gold standard and it is not possible to determine which method is more accurate.

A significant correlation was found between fusion accomplishment and whether the imaging was analysed by a radiologist or a clinician. Since the articles used in this analysis did not provide additional information on this topic, and none of the articles compared radiologists and clinicians, no explanation towards this difference can be given.

The lack of a generally accepted definition of fusion is due to the absence of studies that compare fusion in an intervention group with fusion in control groups. Observing bridging of bone trabeculae on X-ray or CT scans is a qualitative measure. Measuring movement on flexion/extension 
Table 9 Clinical outcome was assessed in correlation to fusion in 18 studies

\begin{tabular}{|c|c|c|c|c|c|c|}
\hline Reference & Bias & Patients $(n)$ & Fusion $(\%)$ & Method of fusion measure & Outcome measure & Correlation \\
\hline Cabraja et al. [112] & 6 & 86 & 90.7 & Flexion/extension X-ray & $\begin{array}{l}\text { VAS neck + arm, NDI and } \\
\text { Odom's criteria }\end{array}$ & No correlation \\
\hline Choi et al. [117] & 5 & 109 & 91.6 & Flexion/extension X-ray & $\begin{array}{l}\text { VAS neck + arm and Robin- } \\
\text { son's criteria }\end{array}$ & No correlation \\
\hline Kim et al. [25] & 5 & 96 & 100 & Flexion/extension X-ray & $\begin{array}{l}\text { VAS (NS) and Odom's } \\
\text { criteria }\end{array}$ & No correlation \\
\hline Klingler et al. [109] & 7 & 107 & 52.3 & CT: trabeculae & $\begin{array}{l}\text { VAS (NS), NDI, SF-36 and } \\
\text { PSI }\end{array}$ & $\begin{array}{l}\text { In the PMMA group, } \\
\text { fused patients showed a } \\
\text { statistically significant } \\
\text { better physical component } \\
\text { summary of the SF-36 } \\
\text { than non-fused patients } \\
(p=0.024) \text {. There was no } \\
\text { correlation in the other } \\
\text { outcome measures or in } \\
\text { the PEEK group }\end{array}$ \\
\hline Moon et al. [105] & 4 & 27 & 77.8 & Flexion/extension X-ray & VAS neck + arm and NDI & No correlation \\
\hline Nunley et al. [118] & 7 & 66 & 85.0 & Flexion/extension X-ray & VAS (NS) and NDI & No correlation \\
\hline Park et al. [119] & 8 & 31 & 90.3 & CT: trabeculae & $\begin{array}{l}\text { VAS (NS), NDI and Odom's } \\
\text { criteria }\end{array}$ & No correlation \\
\hline Ragab et al. [37] & 6 & 35 & 97.1 & Plain X-ray: trabeculae & Not specified & No correlation \\
\hline Ramzi et al. [107] & 6 & 40 & 45.0 & Flexion/extension X-ray & VAS neck + arm & No correlation \\
\hline Samartzis et al. [40] & 5 & 69 & 95.7 & Plain X-ray: trabeculae & Odom's criteria & No correlation \\
\hline Scholz et al. [84] & 7 & 53 & 97.0 & CT: trabeculae & VAS neck + arm and NPDI-G & No correlation \\
\hline Schroder et al. [120] & 7 & 100 & 74.0 & Plain X-ray: trabeculae & Odom's criteria & $\begin{array}{l}\text { Evidence of fusion was } \\
\text { correlated with excellent/ } \\
\text { good results, and the } \\
\text { absence of fusion was cor- } \\
\text { related with satisfactory/ } \\
\text { poor results }(p=0.0364)\end{array}$ \\
\hline Shiban et al. [121] & 6 & 265 & 92.0 & Flexion/extension X-ray & VAS neck + arm and EQ-5D & No correlation \\
\hline Wang et al. [95] & 7 & 16 & 93.8 & CT: trabeculae & $\begin{array}{l}\text { Odom's criteria and JOA- } \\
\text { score }\end{array}$ & No correlation \\
\hline Wright et al. [122] & 7 & 97 & 82.9 & Flexion/extension X-ray & VAS neck + arm & $\begin{array}{l}\text { The absence of fusion was } \\
\text { correlated with higher } \\
\text { VAS scores for neck pain }\end{array}$ \\
\hline Yan et al. [63] & 6 & 32 & 100 & Plain X-ray: trabeculae & Odom's criteria & No correlation \\
\hline Yoo et al. [116] & 7 & 58 & 74.1 & Flexion/extension X-ray & $\begin{array}{l}\text { VAS neck + arm, Odom's } \\
\text { criteria and NDI }\end{array}$ & No correlation \\
\hline Zhou et al. [123] & 6 & 15 & 93.3 & CT: trabeculae & $\begin{array}{l}\text { JOA-score and Odom's } \\
\text { criteria }\end{array}$ & No correlation \\
\hline
\end{tabular}

$V A S$ visual analogue scale, $N S$ not specified. $N D I$ neck disability index. $S F-36$ short-form 36 health survey, $P S I$ patient satisfaction index, $P M M A$ poly-methyl-methacrylate. $P E E K$ polyether ether ketone, $N P D I-G$ neck pain and disability index, German version. EQ-5D EuroQol five-dimensional questionnaire, JOA Japanese orthopaedic association

is quantitative and can serve as a method to develop a gold standard. Ouchida and colleagues [124] claim that flexion-deflexion is more accurately measured on dynamic CT scans in comparison with dynamic X-rays, though again a control group is lacking. A solution could be to consider "the definite fusion group" in a group of patients treated with an intervertebral device. The "definite fusion group" may be formed by patients that demonstrated overgrowth of bone along and through the device. If those patients serve as controls for the other patients, the variation around the 0 degree or 0 -mm movement measure, attributable to the measuring method, could be established. This can help in establishing a critical value above which the absence of fusion could be defined.

Another method was introduced by Johnsson and colleagues [125], who introduced metallic markers in the adjacent bony structures to enable observing movement of the vertebrae. Nevertheless, the accuracy was limited to $0.5-0.7 \mathrm{~mm}$ 
and $0.5-2$ degrees in this study, which was performed in the lumbar spine. Therefore, it seems inadequate to use a cut-off value of 2 degrees to decide on fusion in the cervical spine, like some of the articles included in this review have done.

A minority of studies $(n=18)$ examined the correlation between accomplishment of bony fusion and clinical outcome. Only 3 studies demonstrated a correlation between the absence of fusion and worse clinical outcome, 15 studies did not find a statistically significant correlation. Studies that did find a correlation had lower bony fusion rates than studies that did not find a correlation, which could mean that the studies that did not find a correlation did not have enough power to statistically assess a correlation between fusion and clinical outcome. Furthermore, none of these studies correlated clinical outcome with accomplishment of fusion at different time points. It would be interesting to examine improvement of clinical outcome correlated with accomplishment of bony fusion over time. A recent study did demonstrate a correlation between the absence of fusion and neck pain and considered two time-points [124]. Patients with fusion at 6 months had less neck pain than without fusion at 6 months, and patients with fusion at 12 months had less neck pain than those without fusion at 12 months. However, the number of patients studied was relatively low. Also, the difference in neck pain between months 6 and 12, nor the difference in fusion, nor the correlation between those 2 was studied.

In future studies, it is recommended to evaluate clinical condition in correlation with bony fusion in an earlier phase of the fusion process, when fusion is not yet accomplished in the majority of patients. Conclusions on the correlation of bony fusion and clinical condition cannot be drawn based on the available literature.

Articles with high risk of bias reported higher percentages of bony fusion accomplishment than articles with low risk of bias. In articles with a high risk of bias, the method of measuring bony fusion was often not described, therefore, the higher fusion rates can be due to improper determining of bony fusion.

When comparing different types of implants, bone growth stimulating agents, plates or cages with screws and dimensional aspects of the implant, minor statistically significant differences are found in bony fusion accomplishment, which do not reach clinically relevant numbers, in regard to the MCID. Small differences in bony fusion results will likely not be of importance, if a correlation with clinical outcome cannot be established.

\section{Conclusion}

Fusion as a long-term result after ACDF is satisfactory, but lack of a generally accepted definition of bony fusion and differences in study design hamper conclusions on optimising the rate of bony fusion by choice of material and/ or additives. Overall, it can be concluded that 12 months of follow-up after ACDF is sufficient.

\section{Compliance with ethical standards}

Conflict of interest All authors declare that they have no conflict of interest.

Open Access This article is distributed under the terms of the Creative Commons Attribution 4.0 International License (http://creativeco mmons.org/licenses/by/4.0/), which permits unrestricted use, distribution, and reproduction in any medium, provided you give appropriate credit to the original author(s) and the source, provide a link to the Creative Commons license, and indicate if changes were made.

\section{References}

1. Cloward RB (1958) The anterior approach for removal of ruptured cervical disks. J Neurosurg 15(6):602-617. https://doi. org/10.3171/jns.1958.15.6.0602

2. Fowler SB, Anthony-Phillips P, Mehta D, Liebman K (2005) Health-related quality of life in patients undergoing anterior cervical discectomy fusion. J Neurosci Nurs J Am Assoc Neurosci Nurses 37(2):97-100

3. Smith GW, Robinson RA (1958) The treatment of certain cervical-spine disorders by anterior removal of the intervertebral disc and interbody fusion. J Bone Joint Surg Am 40-A(3):607-624

4. Lee CH, Hyun SJ, Kim MJ, Yeom JS, Kim WH, Kim KJ, Jahng TA, Kim HJ, Yoon SH (2013) Comparative analysis of 3 different construct systems for single-level anterior cervical discectomy and fusion: stand-alone cage, iliac graft plus plate augmentation, and cage plus plating. J Spinal Disord Techn 26(2):112-118. https://doi.org/10.1097/BSD.0b013e318274148e

5. Schmieder K, Wolzik-Grossmann M, Pechlivanis I, Engelhardt M, Scholz M, Harders A (2006) Subsidence of the wing titanium cage after anterior cervical interbody fusion: 2-year follow-up study. J Neurosurg Spine 4(6):447-453. https://doi.org/10.3171/ spi.2006.4.6.447

6. Furlan AD, Pennick V, Bombardier C, van Tulder M (2009) 2009 updated method guidelines for systematic reviews in the Cochrane Back Review Group. Spine 34(18):1929-1941. https ://doi.org/10.1097/BRS.0b013e3181b1c99f

7. Ostelo RW, Deyo RA, Stratford P, Waddell G, Croft P, Von Korff M, Bouter LM, de Vet HC (2008) Interpreting change scores for pain and functional status in low back pain: towards international consensus regarding minimal important change. Spine 33(1):90-94. https://doi.org/10.1097/BRS.0b013e31815e3a10

8. Orief T, Ramadan I, Seddik Z, Kamal M, Rahmany M, Takayasu M (2010) Comparative evaluation of bone-filled Polymethylmethacrylate implant, autograft fusion, and Polyetheretherketone cervical cage fusion for the treatment of single -level cervical disc disease. Asian J Neurosurg 5(2):46-56

9. Acharya S, Kumar S, Srivastava A, Tandon R (2011) Early results of one-level cervical discectomy and fusion with standalone cervical cage and bone marrow soaked tricalcium phosphate. Acta Orthop Belg 77(2):218-223

10. Baskin DS, Ryan P, Sonntag V, Westmark R, Widmayer MA (2003) A prospective, randomized, controlled cervical fusion study using recombinant human bone morphogenetic protein-2 with the CORNERSTONE-SR allograft ring and the ATLANTIS 
anterior cervical plate. Spine 28(12):1219-1224. https://doi. org/10.1097/01.brs.0000065486.22141.ca (discussion 1225)

11. Bhadra AK, Raman AS, Casey AT, Crawford RJ (2009) Singlelevel cervical radiculopathy: clinical outcome and cost-effectiveness of four techniques of anterior cervical discectomy and fusion and disc arthroplasty. Eur Spine J Off Publ Eur Spine Soc Eur Spinal Deform Soc Eur Sect Cerv Spine Res Soc 18(2):232237. https://doi.org/10.1007/s00586-008-0866-8

12. Chang-Jung C, Yi-Jie K, Yueh-Feng C, Rau G, Yang-Hwei T (2008) Anterior cervical fusion using a polyetheretherketone cage containing a bovine xenograftp: three to five-year followup. Spine 33(23):2524-2528

13. Chen JF, Wu CT, Lee SC, Lee ST (2005) Use of a polymethylmethacrylate cervical cage in the treatment of single-level cervical disc disease. J Neurosurg Spine 3(1):24-28. https://doi. org/10.3171/spi.2005.3.1.0024

14. Chen JF, Wu CT, Lee ST (2009) The use of a hollow polymethylmethacrylate cervical spacer with plating in the treatment of single level cervical disc disease. Chang Gung Med J 32(4):447-454

15. Cho DY, Lee WY, Sheu PC, Chen CC (2005) Cage containing a biphasic calcium phosphate ceramic (Triosite) for the treatment of cervical spondylosis. Surg Neurol 63(6):497-503. https://doi. org/10.1016/j.surneu.2004.10.016 (discussion 494-503)

16. Chou YC, Chen DC, Hsieh WA, Chen WF, Yen PS, Harnod T, Chiou TL, Chang YL, Su CF, Lin SZ, Chen SY (2008) Efficacy of anterior cervical fusion: comparison of titanium cages, polyetheretherketone (PEEK) cages and autogenous bone grafts. J Clin Neurosci Off J Neurosurg Soc Australas 15(11):1240-1245. https://doi.org/10.1016/j.jocn.2007.05.016

17. Dai LY, Jiang LS (2008) Anterior cervical fusion with interbody cage containing beta-tricalcium phosphate augmented with plate fixation: a prospective randomized study with 2-year follow-up. Eur Spine J Off Publ Eur Spine Soc Eur Spinal Deform Soc Eur Sect Cerv Spine Res Soc 17(5):698-705. https://doi.org/10.1007/ s00586-008-0643-8

18. Debusscher F, Aunoble S, Alsawad Y, Clement D, Le Huec JC (2009) Anterior cervical fusion with a bio-resorbable composite cage (beta TCP-PLLA): clinical and radiological results from a prospective study on 20 patients. Eur Spine J Off Publ Eur Spine Soc Eur Spinal Deform Soc Eur Sect Cerv Spine Res Soc 18(9):1314-1320. https://doi.org/10.1007/s00586-009-1062-1

19. Fiere V, Greff G, Mosnier T, Faline A (2013) New cervical compressive staple: in vitro testing and early clinical results. J Spinal Disord Techn 26(7):385-392. https://doi.org/10.1097/ BSD.0b013e31824a03d2

20. Grasso G, Giambartino F, Tomasello G, Iacopino G (2014) Anterior cervical discectomy and fusion with ROI-C peek cage: cervical alignment and patient outcomes. Eur Spine J Off Publ Eur Spine Soc Eur Spinal Deform Soc Eur Sect Cerv Spine Res Soc 23(Suppl 6):650-657. https://doi.org/10.1007/s0058 6-014-3553-y

21. Gu Y, Yang HL, Chen L, Dong RB, Han GS, Wu GZ, Chen KW, Tang TS (2009) Use of an integrated anterior cervical plate and cage device (PCB) in cervical anterior fusion. J Clin Neurosci Off J Neurosurg Soc Australas 16(11):1443-1448. https://doi. org/10.1016/j.jocn.2009.02.025

22. Ha BY, Sim HB, Lyo IU, Park ES, Kwon SC, Park JB (2012) Comparisons of two-level discectomy and fusion with cage alone versus single-level corpectomy and fusion with plate in the treatment of cervical degenerative disc disease. Korean J Spine 9(3):197-204. https://doi.org/10.14245/kjs.2012.9.3.197

23. Iwasaki K, Ikedo T, Hashikata H, Toda H (2014) Autologous clavicle bone graft for anterior cervical discectomy and fusion with titanium interbody cage. J Neurosurg Spine 21(5):761-768. https://doi.org/10.3171/2014.7.spine131000
24. Ji GY, Oh CH, Shin DA, Ha Y, Kim KN, Yoon DH, Yudoyono F (2015) Stand-alone cervical cages versus anterior cervical plates in 2-level cervical anterior interbody fusion patients. J Spinal Disord Techn 28(7):E433-E438

25. Kim S, Chun HJ, Yi HJ, Bak KH, Kim DW, Lee YK (2012) Long-term follow-up radiologic and clinical evaluation of cylindrical cage for anterior interbody fusion in degenerative cervical disc disease. J Korean Neurosurg Soc 52(2):107-113

26. Kim SC, Kang SW, Kim SH, Cho KH, Kim SH (2009) Clinical and radiological outcomes of anterior cervical interbody fusion using hydroxyapatite spacer. J Korean Neurosurg Soc 46(4):300 304. https://doi.org/10.3340/jkns.2009.46.4.300

27. Lane PD, Cox JL, Gaskins RB 3rd, Santoni BG, Billys JB, Castellvi AE (2015) Early radiographic and clinical outcomes study evaluating an integrated screw and interbody spacer for one- and two-level ACDF. Int J Spine Surg 9:39. https://doi. org/10.14444/2039

28. Li J, Zheng Q, Guo X, Zeng X, Zou Z, Liu Y, Hao S (2013) Anterior surgical options for the treatment of cervical spondylotic myelopathy in a long-term follow-up study. Arch Orthop Trauma Surg 133(6): 745-751

29. Liao JC, Niu CC, Chen WJ, Chen LH (2008) Polyetheretherketone (PEEK) cage filled with cancellous allograft in anterior cervical discectomy and fusion. Int Orthop 32(5):643-648. https://doi.org/10.1007/s00264-007-0378-x

30. Liu J, Xiong X, Long X, Shu Y, Huang S, Yang D, Liu Z (2015) A new source of structural autograft for ACDF surgery: cervical laminae. Int J Clin Exp Med 8(6):9100-9106

31. Luo J, Huang S, Gong M, Li L, Yu T, Zou X (2015) Two-level anterior cervical discectomy and fusion using self-locking stand-alone polyetheretherketone cages with two anchoring clips placed in the upper and lower vertebrae, respectively. Eur J Orthop Surg Traumatol Orthop Traumatol 25(Suppl 1):S147S153. https://doi.org/10.1007/s00590-015-1613-6

32. Mastronardi L, Ducati A, Ferrante L (2006) Anterior cervical fusion with polyetheretherketone (PEEK) cages in the treatment of degenerative disc disease. Preliminary observations in 36 consecutive cases with a minimum 12-month follow-up. Acta Neurochir 148(3):307-312

33. Nagata T, Takami T, Yamagata T, Uda T, Naito K, Ohata K (2011) Significant relationship between local angle at fused segments and C2-7 angle: average duration of longer than 20 years after anterior cervical discectomy and fusion. $\mathbf{J}$ Craniovertebral Junct Spine 2(2):62-66

34. Nemoto O, Kitada A, Naitou S, Tachibana A, Ito Y, Fujikawa A (2015) Stand-alone anchored cage versus cage with plating for single-level anterior cervical discectomy and fusion: a prospective, randomized, controlled study with a 2-year followup. Eur J Orthop Surg Traumatol Orthop Traumatol 25(Suppl 1):S127-S134. https://doi.org/10.1007/s00590-014-1547-4

35. Niu CC, Liao JC, Chen WJ, Chen LH (2010) Outcomes of interbody fusion cages used in 1 and 2-levels anterior cervical discectomy and fusion: titanium cages versus polyetheretherketone (PEEK) cages. J Spinal Disord Techn 23(5):310-316. https://doi.org/10.1097/BSD.0b013e3181af3a84

36. Peelle MW, Rawlins BA, Frelinghuysen P (2007) A novel source of cancellous autograft for ACDF surgery: the manubrium. J Spinal Disord Techn 20(1):36-41. https://doi. org/10.1097/01.bsd.0000211230.89554.5c

37. Ragab AA, Hodges FS, Hill CP, McGuire RA, Tucci M (2010) Dynamic anterior cervical plating for multi-level spondylosis: does it help? Evid Based Spine-Care J 1(1):41-46. https://doi. org/10.1055/s-0028-1100892

38. Ryu SI, Mitchell M, Kim DH (2006) A prospective randomized study comparing a cervical carbon fiber cage to the SmithRobinson technique with allograft and plating: up to 24 months 
follow-up. Eur Spine J Off Publ Eur Spine Soc Eur Spinal Deform Soc Eur Sect Cerv Spine Res Soc 15(2):157-164. https ://doi.org/10.1007/s00586-005-0951-1

39. Salame K, Ouaknine GE, Razon N, Rochkind S (2002) The use of carbon fiber cages in anterior cervical interbody fusion: report of 100 cases. Neurosurg Focus 12(1):E1. https://doi. org/10.3171/foc.2002.12.1.2

40. Samartzis D, Shen FH, Lyon C, Phillips M, Goldberg EJ, An HS (2004) Does rigid instrumentation increase the fusion rate in one-level anterior cervical discectomy and fusion? Spine J Off J North Am Spine Soc 4(6):636-643. https://doi. org/10.1016/j.spinee.2004.04.010

41. Sangala JR, Nichols T, Uribe JS, Melton M, Vale FL (2010) Sternal cancellous bone graft harvest for anterior cervical discectomy and fusion with interbody cage devices. Clin Neurol Neurosurg 112(6):470-473. https://doi.org/10.1016/j.cline uro.2010.03.011

42. Schils F, Rilliet B, Payer M (2006) Implantation of an empty carbon fiber cage or a tricortical iliac crest autograft after cervical discectomy for single-level disc herniation: a prospective comparative study. J Neurosurg Spine 4(4):292-299. https://doi. org/10.3171/spi.2006.4.4.292

43. Scholz M, Schnake KJ, Pingel A, Hoffmann R, Kandziora F (2011) A new zero-profile implant for stand-alone anterior cervical interbody fusion. Clin Orthop Relat Res 469(3):666-673. https://doi.org/10.1007/s11999-010-1597-9

44. Shen FH, Samartzis D, Khanna N, Goldberg EJ, An HS (2004) Comparison of clinical and radiographic outcome in instrumented anterior cervical discectomy and fusion with or without direct uncovertebral joint decompression. Spine J 4(6):629-635

45. Shin SH, Lee WJ, Eun JP, Choi HY, Lee JC (2007) Clinical and radiologic assessment for anterior cervical interbody fusion with synthetic cages. J Korean Neurosurg Soc 41(2):105-110

46. Siam AE, El Saghir H, El-Fiky T, Moustafa O, El Mansy Y (2014) Results of ACDF using Alexandria modular cage-plate construct in cervical canal stenosis. Eur Orthop Traumatol 5(2):131-137

47. Singh D, Sinha S, Singh H, Jagetia A, Gupta S, Gangoo P, Tandon M (2011) Use of nitinol shape memory alloy staples (NiTi clips) after cervical discoidectomy: minimally invasive instrumentation and long-term results. Minim Invasive Neurosurg MIN 54(4):172-178. https://doi.org/10.1055/s-0031-12843 99

48. Song KJ, Lee KB (2006) A preliminary study of the use of cage and plating for single-segment fusion in degenerative cervical spine disease. J Clin Neurosci Off J Neurosurg Soc Australas 13(2):181-187. https://doi.org/10.1016/j.jocn.2005.02.018

49. Sugawara T, Itoh Y, Hirano Y, Higashiyama N, Mizoi K (2011) beta-Tricalcium phosphate promotes bony fusion after anterior cervical discectomy and fusion using titanium cages. Spine 36(23):E1509-E1514. https://doi.org/10.1097/BRS.0b013e3182 $0 \mathrm{e} 60 \mathrm{~d} 9$

50. Tan J, Zheng Y, Gong L, Liu X, Li J, Du W (2008) Anterior cervical discectomy and interbody fusion by endoscopic approach: a preliminary report. J Neurosurg Spine 8(1):17-21. https://doi. org/10.3171/spi-08/01/017

51. Tancredi A, Agrillo A, Delfini R, Fiume D, Frati A, Rinaldi A (2004) Use of carbon fiber cages for treatment of cervical myeloradiculopathies. Surg Neurol 61(3):221-226. https://doi. org/10.1016/j.surneu.2003.07.014 (discussion 226)

52. Wang C, Zhang Y, Yuan W (2014) Early clinical outcomes and radiographic features after treatment of cervical degenerative disc disease with the new zero-profile implant: a one-year follow-up retrospective study. J Spinal Disord Techn. https://doi. org/10.1097/bsd.0000000000000101
53. Wang MY, Liu CY (2005) Resorbable polylactic acid interbody spacers with vertebral autograft for anterior cervical discectomy and fusion. Neurosurgery 57(1):135-140 (discussion 135-140)

54. Wang X, Chen Y, Chen D, Yuan W, Chen X, Zhou X, Xiao J, Ni B, Jia L (2009) Anterior decompression and interbody fusion with BAK/C for cervical disc degenerative disorders. J Spinal Disord Techn 22(4):240-245. https://doi.org/10.1097/ BSD.0b013e31816d5f7e

55. Wang Z, Jiang W, Li X, Wang H, Shi J, Chen J, Meng B, Yang H (2014) The application of zero-profile anchored spacer in anterior cervical discectomy and fusion. Eur Spine J 24(1):148-154

56. Wang Z, Zhu R, Yang H, Shen M, Wang G, Chen K, Gan M, Li $M(2015)$ Zero-profile implant (Zero-p) versus plate cage benezech implant (PCB) in the treatment of single-level cervical spondylotic myelopathy. BMC Musculoskelet Disord 16:290. https://doi.org/10.1186/s12891-015-0746-4

57. Wei F, Wang L, Zhou Z, Zhong R, Liu S, Cui S, Pan X, Gao $M$ (2015) Cervical cage without plating in management of type II/II A Hangman's fracture combined with intervertebral disc injury. BMC Musculoskelet Disord 16:285. https://doi. org/10.1186/s12891-015-0734-8

58. Wilkinson JS, Mann SA, Stoneham GW, Hentschel S, Fourney DR (2011) Comparison of post-operative lordosis with the PEEK cage and the cervical plate. Can J Neurol Sci Le J Can des Sci Neurol 38(1):72-77

59. Woiciechowsky C, Thomale UW, Kroppenstedt SN (2004) Degenerative spondylolisthesis of the cervical spine-symptoms and surgical strategies depending on disease progress. Eur Spine J 13(8):680-684

60. Wu WJ, Jiang LS, Liang Y, Dai LY (2012) Cage subsidence does not, but cervical lordosis improvement does affect the long-term results of anterior cervical fusion with stand-alone cage for degenerative cervical disc disease: a retrospective study. Eur Spine J Off Publ Eur Spine Soc Eur Spinal Deform Soc Eur Sect Cerv Spine Res Soc 21(7):1374-1382. https:// doi.org/10.1007/s00586-011-2131-9

61. Xie Y, Li H, Yuan J, Fu L, Yang J, Zhang P (2015) A prospective randomized comparison of PEEK cage containing calcium sulphate or demineralized bone matrix with autograft in anterior cervical interbody fusion. Int Orthop 39(6):1129-1136. https://doi.org/10.1007/s00264-014-2610-9

62. Yan D, Li J, Zhang Z (2014) Anterior cervical discectomy and fusion with the zero-profile implant system for cervical spondylotic myelopathy. Techn Orthop 29(1):49-53

63. Yan JL, Chen JF, Lee ST, Chang CN, Liao CC (2014) Surgical outcomes of Cervios ChronOS cage implantation for degenerative cervical Intervertebral disk disorder. Neurosurg Q 24(3):161-166

64. Yang L, Gu Y, Liang L, Gao R, Shi S, Shi J, Yuan W (2012) Stand-alone anchored spacer versus anterior plate for multilevel anterior cervical diskectomy and fusion. Orthopedics 35(10):e1503-e1510. https://doi.org/10.3928/01477447-20120 919-20

65. Yao N, Wang C, Wang W, Wang L (2011) Full-endoscopic technique for anterior cervical discectomy and interbody fusion: 5-year follow-up results of 67 cases. Eur Spine J Off Publ Eur Spine Soc Eur Spinal Deform Soc Eur Sect Cerv Spine Res Soc 20(6):899-904. https://doi.org/10.1007/s0058 6-010-1642-0

66. Zagra A, Zagra L, Scaramuzzo L, Minoia L, Archetti M, Giudici F (2013) Anterior cervical fusion for radicular-disc conflict performed by three different procedures: clinical and radiographic analysis at long-term follow-up. Eur Spine J 22:S905-S909

67. Zhou J, Xia Q, Dong J, Li X, Zhou X, Fang T, Lin H (2011) Comparison of stand-alone polyetheretherketone cages and iliac crest autografts for the treatment of cervical degenerative 
disc diseases. Acta Neurochir 153(1):115-122. https://doi. org/10.1007/s00701-010-0821-4

68. Chang MY, Chen MH, Chang CJ, Huang JS (2013) Preliminary clinical experience with polyetheretherketone cages filled with synthetic crystallic semihydrate form of calcium sulfate for anterior cervical discectomy and fusion. Formos J Surg 46(4):109-115

69. Cho HJ, Hur JW, Lee JB, Han JS, Cho TH, Park JY (2015) Cervical stand-alone polyetheretherketone cage versus zero-profile anchored spacer in single-level anterior cervical discectomy and fusion: minimum 2-year assessment of radiographic and clinical outcome. J Korean Neurosurg Soc 58(2):119-124. https://doi. org/10.3340/jkns.2015.58.2.119

70. Eastlack RK, Garfin SR, Brown CR, Meyer SC (2014) Osteocel Plus cellular allograft in anterior cervical discectomy and fusion: evaluation of clinical and radiographic outcomes from a prospective multicenter study. Spine 39(22):E1331-E1337. https://doi. org/10.1097/brs.0000000000000557

71. El-Tantawy A (2015) Is it possible to eliminate the plate-related problems and still achieve satisfactory outcome after multilevel anterior cervical discectomy? Eur J Orthop Surg Traumatol Orthop Traumatol 25(Suppl 1):S135-S145. https://doi. org/10.1007/s00590-015-1611-8

72. Farrokhi MR, Nikoo Z, Gholami M, Hosseini K (2015) Comparison between acrylic cage and polyetheretherketone (PEEK) cage in single-level anterior cervical discectomy and fusion: a randomized clinical trial. J Spinal Disord Techn. https://doi. org/10.1097/bsd.0000000000000251

73. Fernandez-Fairen M, Sala P, Dufoo M Jr, Ballester J, Murcia A, Merzthal L (2008) Anterior cervical fusion with tantalum implant: a prospective randomized controlled study. Spine 33(5):465-472

74. Hacker RJ, Cauthen JC, Gilbert TJ, Griffith SL (2000) A prospective randomized multicenter clinical evaluation of an anterior cervical fusion cage. Spine 25(20):2646-2654 (discussion 2655)

75. Hofstetter CP, Kesavabhotla K, Boockvar JA (2015) Zero-profile anchored spacer reduces rate of dysphagia compared with ACDF with anterior plating. J Spinal Disord Techn 28(5):E284-E290. https://doi.org/10.1097/BSD.0b013e31828873ed

76. Kim CH, Chung CK, Hahn S (2013) Autologous iliac bone graft with anterior plating is advantageous over the stand-alone cage for segmental lordosis in single-level cervical disc disease. Neurosurgery 72(2):257-265. https://doi.org/10.1227/neu.0b013 e $31827 b 94 d 4$ (discussion 266)

77. Lee CH, Kim KJ, Hyun SJ, Yeom JS, Jahng TA, Kim HJ (2015) Subsidence as of 12 months after single-level anterior cervical inter-body fusion. Is it related to clinical outcomes? Acta Neurochir 157(6):1063-1068. https://doi.org/10.1007/s0070 1-015-2388-6

78. Mashhadinezhad H, Samini F, Zare R (2014) Comparison of outcomes and safety of using hydroxyapatite granules as a substitute for autograft in cervical cages for anterior cervical discectomy and interbody fusion. Arch Bone Joint Surg 2(1):37-42

79. Mobbs RJ, Rao P, Chandran NK (2007) Anterior cervical discectomy and fusion: analysis of surgical outcome with and without plating. J Clin Neurosci Off J Neurosurg Soc Australas 14(7):639-642. https://doi.org/10.1016/j.jocn.2006.04.003

80. Oh HS, Shim CS, Kim JS, Lee SH (2013) Clinical and radiological comparison of femur and fibular allografts for the treatment of cervical degenerative disc diseases. J Korean Neurosurg Soc 53(1):6-12. https://doi.org/10.3340/jkns.2013.53.1.6

81. Park JH, Roh SW (2013) Anterior cervical interbody fusion using polyetheretherketone cage filled with autologous and synthetic bone graft substrates for cervical spondylosis: comparative analysis between polybone and iliac bone. Neurol Med Chir 53(2):85-90

82. Pourtaheri S, Hwang K, Faloon M, Issa K, Mease SJ, Mangels D, Sinha K, Emami A (2015) Ultra-low-dose recombinant human bone morphogenetic protein-2 for 3-level anterior cervical diskectomy and fusion. Orthopedics 38(4):241-245

83. Saphier PS, Arginteanu MS, Moore FM, Steinberger AA, Camins MB (2007) Stress-shielding compared with load-sharing anterior cervical plate fixation: a clinical and radiographic prospective analysis of 50 patients. J Neurosurg Spine 6(5):391-397. https ://doi.org/10.3171/spi.2007.6.5.391

84. Scholz M, Schelfaut S, Pingel A, Schleicher P, Kandziora F (2014) A cervical "zero-profile" cage with integrated angle-stable fixation: 24-months results. Acta Orthop Belg 80(4):558-566

85. Shad A, Leach JC, Teddy PJ, Cadoux-Hudson TA (2005) Use of the Solis cage and local autologous bone graft for anterior cervical discectomy and fusion: early technical experience. J Neurosurg Spine 2(2):116-122. https://doi.org/10.3171/ spi.2005.2.2.0116

86. Song J, Taghavi CE, Hsu DW, Song KJ, Song JH, Lee KB (2012) Radiological changes in anterior cervical discectomy and fusion with cage and plate construct: the significance of the anterior spur formation sign. Spine 37(4):272-279. https://doi. org/10.1097/BRS.0b013e31821c3cbf

87. Song KJ, Taghavi CE, Hsu MS, Lee KB, Kim GH, Song JH (2010) Plate augmentation in anterior cervical discectomy and fusion with cage for degenerative cervical spinal disorders. Eur Spine J Off Publ Eur Spine Soc Eur Spinal Deform Soc Eur Sect Cerv Spine Res Soc 19(10):1677-1683. https://doi.org/10.1007/ s00586-010-1283-3

88. Song KJ, Taghavi CE, Lee KB, Song JH, Eun JP (2009) The efficacy of plate construct augmentation versus cage alone in anterior cervical fusion. Spine 34(26):2886-2892. https://doi. org/10.1097/BRS.0b013e3181b64f2c

89. Suchomel P, Barsa P, Buchvald P, Svobodnik A, Vanickova E (2004) Autologous versus allogenic bone grafts in instrumented anterior cervical discectomy and fusion: a prospective study with respect to bone union pattern. Eur Spine J Off Publ Eur Spine Soc Eur Spinal Deform Soc Eur Sect Cerv Spine Res Soc 13(6):510-515. https://doi.org/10.1007/s00586-003-0667-z

90. Tabaraee E, Ahn J, Bohl DD, Elboghdady IM, Aboushaala K, Singh K (2015) The impact of worker's compensation claims on outcomes and costs following an anterior cervical discectomy and fusion. Spine 40(12):948-953. https://doi.org/10.1097/ brs.0000000000000873

91. Takeuchi M, Yasuda M, Niwa A, Wakao N, Nakura T, Osuka K, Kamiya M, Takayasu M (2014) Plasmapore-coated titanium cervical cages induce more rapid and complete bone fusion after anterior cervical discectomy and fusion as compared to noncoated titanium cages. World Neurosurg 82(3-4):519-522. https://doi.org/10.1016/j.wneu.2013.04.001

92. Tomasino A, Gebhard H, Parikh K, Wess C, Hartl R (2009) Bioabsorbable instrumentation for single-level cervical degenerative disc disease: a radiological and clinical outcome study. J Neurosurg Spine 11(5):529-537. https://doi.org/10.3171/2009.6.spine 08838

93. Topuz K, Colak A, Kaya S, Simsek H, Kutlay M, Demircan MN, Velioglu M (2009) Two-level contiguous cervical disc disease treated with peek cages packed with demineralized bone matrix: results of 3-year follow-up. Eur Spine J Off Publ Eur Spine Soc Eur Spinal Deform Soc Eur Sect Cerv Spine Res Soc 18(2):238243. https://doi.org/10.1007/s00586-008-0869-5

94. Vanek P, Bradac O, DeLacy P, Lacman J, Benes V (2013) Anterior interbody fusion of the cervical spine with zero-P spacer: 
prospective comparative study—clinical and radiological results at a minimum 2 years after surgery. Spine 38(13):E792-E797

95. Wang HR, Li XL, Dong J, Yuan FL, Zhou J (2013) Skip-level anterior cervical discectomy and fusion with self-locking standalone PEEK cages for the treatment of 2 noncontiguous levels of cervical spondylosis. J Spinal Disord Techn 26(7):E286-E292. https://doi.org/10.1097/BSD.0b013e31828679b3

96. Yi J, Lee GW, Nam WD, Han KY, Kim MH, Kang JW, Won J, Kim SW, Noh W, Yeom JS (2015) A prospective randomized clinical trial comparing bone union rate following anterior cervical discectomy and fusion using a polyetheretherketone cage: hydroxyapatite/b-tricalcium phosphate mixture versus hydroxyapatite/demineralized bone matrix mixture. Asian Spine J 9(1):30-38. https://doi.org/10.4184/asj.2015.9.1.30

97. Zigler JE, Delamarter R, Murrey D, Spivak J, Janssen M (2013) ProDisc-C and anterior cervical discectomy and fusion as surgical treatment for single-level cervical symptomatic degenerative disc disease: five-year results of a Food and Drug Administration study. Spine 38(3):203-209. https://doi.org/10.1097/BRS.0b013 e318278eb38

98. Coric D, Kim PK, Clemente JD, Boltes MO, Nussbaum M, James S (2013) Prospective randomized study of cervical arthroplasty and anterior cervical discectomy and fusion with long-term follow-up: results in 74 patients from a single site. J Neurosurg Spine 18(1):36-42. https://doi.org/10.3171/2012.9.spine12555

99. Hauerberg J, Kosteljanetz M, Boge-Rasmussen T, Dons K, Gideon P, Springborg JB, Wagner A (2008) Anterior cervical discectomy with or without fusion with ray titanium cage: a prospective randomized clinical study. Spine 33(5):458-464. https ://doi.org/10.1097/BRS.0b013e3181657dac

100. Hellbusch LC, Spangler WJ, Bowder A (2012) Radiographic PEEK double-lucency finding after anterior cervical discectomy and fusion with local autograft and PEEK spacer: a preliminary study. J Neurosurg Spine 16(3):248-250. https://doi. org/10.3171/2011.11.spine1141

101. Heller JG, Sasso RC, Papadopoulos SM, Anderson PA, Fessler RG, Hacker RJ, Coric D, Cauthen JC, Riew DK (2009) Comparison of BRYAN cervical disc arthroplasty with anterior cervical decompression and fusion: clinical and radiographic results of a randomized, controlled, clinical trial. Spine 34(2):101-107. https ://doi.org/10.1097/BRS.0b013e31818ee263

102. Jagannathan J, Shaffrey CI, Oskouian RJ, Dumont AS, Herrold C, Sansur CA, Jane JA (2008) Radiographic and clinical outcomes following single-level anterior cervical discectomy and allograft fusion without plate placement or cervical collar. J Neurosurg Spine 8(5):420-428. https://doi.org/10.3171/spi/2008/8/5/420

103. Joo YH, Lee JW, Kwon KY, Rhee JJ, Lee HK (2010) Comparison of fusion with cage alone and plate instrumentation in twolevel cervical degenerative disease. J Korean Neurosurg Soc 48(4):342-346. https://doi.org/10.3340/jkns.2010.48.4.342

104. Marbacher S, Hidalgo-Staub T, Kienzler J, Wuergler-Hauri C, Landolt H, Fandino J (2015) Long-term outcome after adjacent two-level anterior cervical discectomy and fusion using stand-alone plasmaphore-covered titanium cages. J Neurol Surg Part A Central Eur Neurosurg 76(3):199-204. https://doi. org/10.1055/s-0034-1382782

105. Moon HJ, Kim JH, Kim JH, Kwon TH, Chung HS, Park YK (2011) The effects of anterior cervical discectomy and fusion with stand-alone cages at two contiguous levels on cervical alignment and outcomes. Acta Neurochir 153(3):559-565. https://doi. org/10.1007/s00701-010-0879-z

106. Oh JK, Kim TY, Lee HS, You NK, Choi GH, Yi S, Ha Y, Kim KN, Yoon DH, Shin HC (2013) Stand-alone cervical cages versus anterior cervical plate in 2-level cervical anterior interbody fusion patients: clinical outcomes and radiologic changes. $\mathbf{J}$
Spinal Disord Techn 26(8):415-420. https://doi.org/10.1097/ BSD.0b013e31824c7d22

107. Ramzi N, Ribeiro-Vaz G, Fomekong E, Lecouvet FE, Raftopoulos C (2008) Long term outcome of anterior cervical discectomy and fusion using coral grafts. Acta Neurochir 150(12):12491256. https://doi.org/10.1007/s00701-008-0140-1 (discussion 1256)

108. Tureyen K, Maciejczak A (2003) Disc height loss after anterior cervical microdiscectomy with titanium intervertebral cage fusion. Acta Neurochir 145(7):565-570

109. Klingler JH, Kruger MT, Sircar R, Kogias E, Scholz C, Volz F, Scheiwe C, Hubbe U (2014) PEEK cages versus PMMA spacers in anterior cervical discectomy: comparison of fusion, subsidence, sagittal alignment, and clinical outcome with a minimum 1-year follow-up. Sci World J 2014:398396. https://doi. org/10.1155/2014/398396

110. Pechlivanis I, Thuring T, Brenke C, Seiz M, Thome C, Barth M, Harders A, Schmieder K (2011) Non-fusion rates in anterior cervical discectomy and implantation of empty polyetheretherketone cages. Spine 36(1):15-20. https://doi.org/10.1097/BRS.0b013 e3181cbf 870

111. Yoshii T, Yuasa M, Sotome S, Yamada T, Sakaki K, Hirai T, Taniyama T, Inose H, Kato T, Arai Y, Kawabata S, Tomizawa S, Enomoto M, Shinomiya K, Okawa A (2013) Porous/dense composite hydroxyapatite for anterior cervical discectomy and fusion. Spine 38(10):833-840. https://doi.org/10.1097/BRS.0b013e3182 801390

112. Cabraja M, Oezdemir S, Koeppen D, Kroppenstedt S (2012) Anterior cervical discectomy and fusion: comparison of titanium and polyetheretherketone cages. BMC Musculoskelet Disord 13:172. https://doi.org/10.1186/1471-2474-13-172

113. Njoku I, Alimi M, Leng LZ, Shin BJ, James AR, Bhangoo S, Tsiouris AJ, Hartl R (2014) Anterior cervical discectomy and fusion with a zero-profile integrated plate and spacer device: a clinical and radiological study. J Neurosurg Spine 21(4):529-537

114. Tani S, Nagashima H, Isoshima A, Akiyama M, Ohashi H, Tochigi S, Abe T (2010) A unique device, the disc space-fitted distraction device, for anterior cervical discectomy and fusion: early clinical and radiological evaluation. J Neurosurg Spine 12(4):342-346. https://doi.org/10.3171/2009.10.spine09283

115. Thome C, Leheta O, Krauss JK, Zevgaridis D (2006) A prospective randomized comparison of rectangular titanium cage fusion and iliac crest autograft fusion in patients undergoing anterior cervical discectomy. J Neurosurg Spine 4(1):1-9. https://doi. org/10.3171/spi.2006.4.1.1

116. Yoo M, Kim WH, Hyun SJ, Kim KJ, Jahng TA, Kim HJ (2014) Comparison between two different cervical interbody fusion cages in one level stand-alone ACDF: carbon fiber composite frame cage versus polyetheretherketone cage. Korean J Spine 11(3):127-135. https://doi.org/10.14245/kjs.2014.11.3.127

117. Choi MK, Kim SB, Park CK, Kim SM (2016) Comparison of the clinical and radiologic outcomes obtained with single- versus two-level anterior cervical decompression and fusion using stand-alone PEEK cages filled with allograft. Acta Neurochir. https://doi.org/10.1007/s00701-015-2692-1

118. Nunley PD, Jawahar A, Kerr EJ 3rd, Cavanaugh DA, Howard C, Brandao SM (2009) Choice of plate may affect outcomes for single versus multilevel ACDF: results of a prospective randomized single-blind trial. Spine J Off J North Am Spine Soc 9(2):121-127. https://doi.org/10.1016/j.spinee.2007.11.009

119. Park JI, Cho DC, Kim KT, Sung JK (2013) Anterior cervical discectomy and fusion using a stand-alone polyetheretherketone cage packed with local autobone: assessment of bone fusion and subsidence. J Korean Neurosurg Soc 54(3):189-193. https://doi. org/10.3340/jkns.2013.54.3.189 
120. Schroder J, Grosse-Dresselhaus F, Schul C, Wassmann H (2007) Anterior cervical spinal fusion with the Intromed ZWE System: preliminary experience. Neurosurg Rev 30(1):63-68. https://doi. org/10.1007/s10143-006-0043-7 (discussion 68)

121. Shiban E, Gapon K, Wostrack M, Meyer B, Lehmberg J (2015) Clinical and radiological outcome after anterior cervical discectomy and fusion with stand-alone empty polyetheretherketone (PEEK) cages. Acta Neurochir. https://doi.org/10.1007/s0070 1-015-2630-2

122. Wright IP, Eisenstein SM (2007) Anterior cervical discectomy and fusion without instrumentation. Spine 32(7):772-774. https ://doi.org/10.1097/01.brs.0000258846.86537.ad (discussion 775)

123. Zhou J, Li X, Dong J, Zhou X, Fang T, Lin H, Ma Y (2011) Three-level anterior cervical discectomy and fusion with self-locking stand-alone polyetheretherketone cages. J Clin Neurosci Off J Neurosurg Soc Australas 18(11):1505-1509. https:// doi.org/10.1016/j.jocn.2011.02.045

124. Ouchida J, Yukawa Y, Ito K, Machino M, Inoue T, Tomita K, Kato F (2015) Functional computed tomography scanning for evaluating fusion status after anterior cervical decompression fusion. v 24(12):2924-2929. https://doi.org/10.1007/s0058 6-014-3722-z

125. Johnsson R, Stromqvist B, Aspenberg P (2002) Randomized radiostereometric study comparing osteogenic protein-1 (BMP7) and autograft bone in human noninstrumented posterolateral lumbar fusion: 2002 Volvo Award in clinical studies. Spine 27(23):2654-2661. https://doi.org/10.1097/01.brs.0000035339 .83704 .60

\section{Affiliations}

\section{Noordhoek ${ }^{1}$ (D) M. T. Koning ${ }^{2}$. C. L. A. Vleggeert-Lankamp ${ }^{1}$}

1 Department of Neurosurgery, Leiden University Medical Centre, Albinusdreef 2, 2300 RC Leiden, The Netherlands
Department of Hematology, Leiden University Medical Centre, Leiden, The Netherlands 